
$\overline{P O S T A L ~ S E R V I C E}_{\otimes}$ (All Periodicals Publications Except Requester Publications)

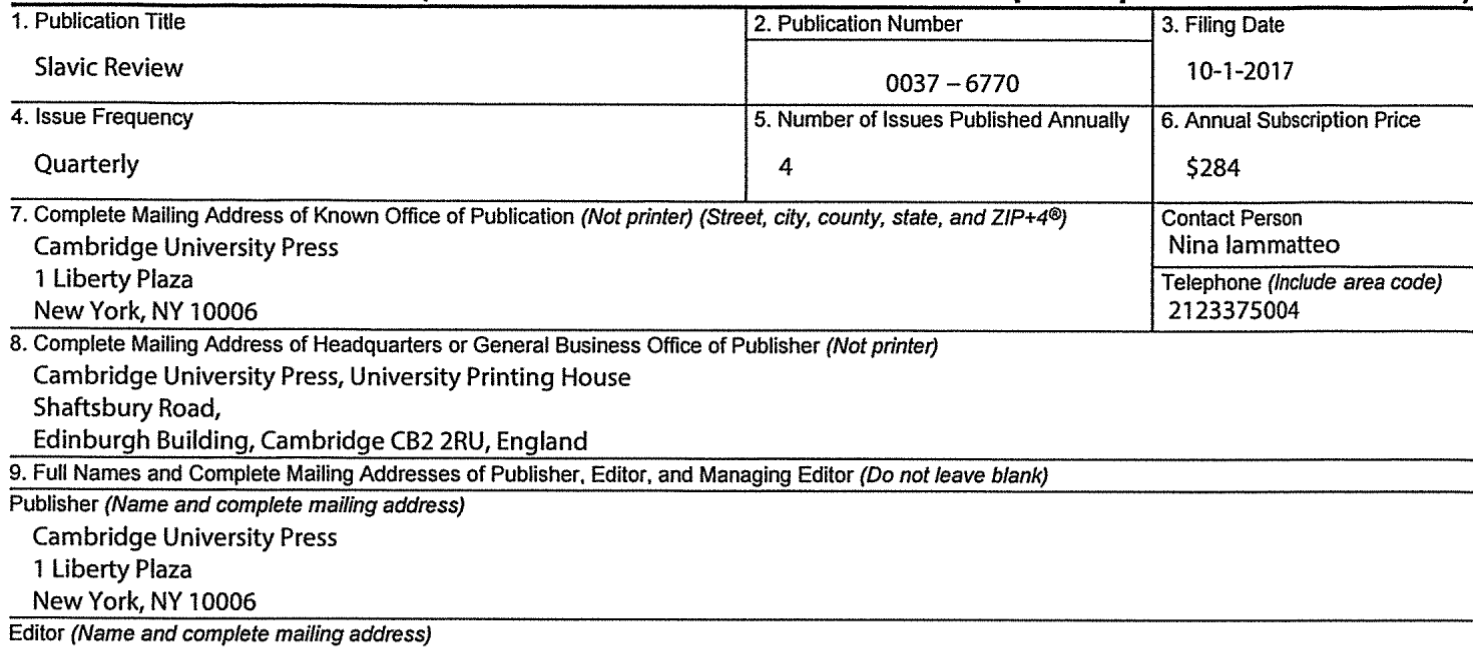

Harriet Murav, University of Illinois, 1207 W.Oregon St.,Urbana, IL 61801-3716

Managing Editor (Name and complete mailing address)

Dmitry Tartakovsky,University of Illinois, 1207 W.Oregon St., Urbana, IL 61801-3716

10. Owner (Do not leave blank. If the publication is owned by a corporation, give the name and address of the corporation immediately followed by the names and addresses of all stockholders owning or holding 1 percent or more of the total amount of stock. If not owned by a corporation, give the names and addresses of the individual owners. If owned by a partnership or other unincorporated firm, give its name and address as well as those of each individual owner. If the publication is published by a nonprofit organization, give its name and address.)

\begin{tabular}{l|l}
\hline Full Name & Complete Mailing Address \\
\hline Association for Slavic,East European,and Eurasian Studies(ASEEES) & $\begin{array}{l}203 \text { C Bellefield Hall, 315 S.Bellefield Avenue, Pittsburgh, PA } \\
15260-6424\end{array}$ \\
\hline & \\
\hline
\end{tabular}

11. Known Bondholders, Mortgagees, and Other Security Holders Owning or Holding 1 Percent or More of Total Amount of Bonds, Mortgages, or Other Securities. If none, check box - 8 None

\begin{tabular}{|c|c|}
\hline Full Name & Complete Mailing Address \\
\hline & \\
\hline & \\
\hline & \\
\hline & \\
\hline \multicolumn{2}{|c|}{$\begin{array}{l}\text { 12. Tax Status (For completion by nonprofit organizations authorized to mail at nonprofit rates) (Check one) } \\
\text { The purpose, function, and nonprofit status of this organization and the exempt status for federal income tax purposes: }\end{array}$} \\
\hline \multicolumn{2}{|c|}{$\otimes$ Has Not Changed During Preceding 12 Months } \\
\hline \multicolumn{2}{|c|}{$\square$ Has Changed During Preceding 12 Months (Publisher must submit explanation of change with this statement) } \\
\hline
\end{tabular}

PS Form 3526, July 2014 [Page 1 of 4 (see instructions page 4)] PSN: 7530-01-000-9931 PRIVACY NOTICE: See our privacy policy on uww.usps.com. 


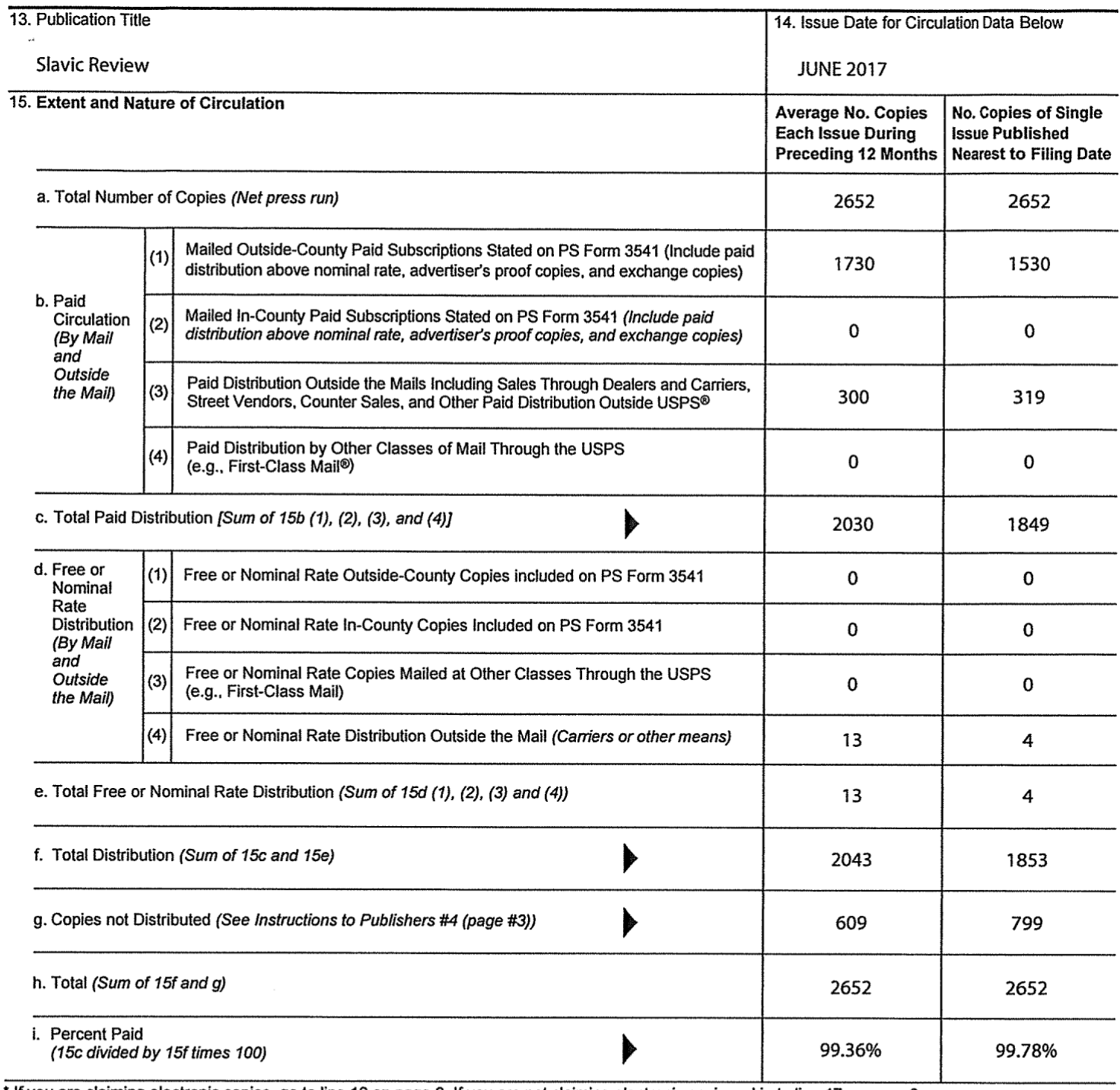

* If you are claiming electronic copies, go to line 16 on page 3 . If you are not claiming electronic copies, skip to line 17 on page 3. 
a. Paid Electronic Copies

b. Total Paid Print Copies (Line 15c) + Paid Electronic Copies (Line 16a)

c. Total Print Distribution (Line 15f) + Paid Electronic Copies (Line 16a)

d. Percent Paid (Both Print \& Electronic Copies) (16b divided by $16 \mathrm{c} \times 100$ )

\begin{tabular}{c|c|c}
\hline & 0 & 0 \\
\hline & 2030 & 1849 \\
\hline & 2043 & 1853 \\
\hline & $99.36 \%$ & $99.78 \%$ \\
\hline
\end{tabular}

QI certify that $50 \%$ of all my distributed copies (electronic and print) are paid above a nominal price.

\section{Publication of Statement of Ownership}

If the publication is a general publication, publication of this statement is required. Will be printed Publication not required. in the Xec issue of this publication

18. Signature and Title of Editor, Publisher, Business Manager, or Owner
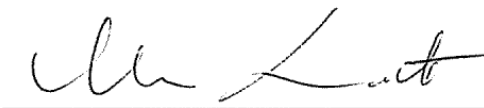

$10-1-2017$

I certify that all information furnished on this form is true and complete. I understand that anyone who furnishes false or misleading information on this form or who omits material or information requested on the form may be subject to criminal sanctions (including fines and imprisonment) and/or civil sanctions (including civil penalties). 
All issues of Slavic Review are available online through Cambridge Core for institutional subscribers and ASEEES members. For more information, please visit https://www.cambridge. org/core/journals/slavic-review/subscribe or contact: online@cambridge.org if you are in the Americas or library.sales@cambridge.org for the rest of the world.

Institutional subscriptions can be purchased direct from Cambridge University Press or through any major subscription agent. Print-only, online-only and bundled print and online prices are all available, and subscription prices are tiered according to institution type and size. Please contact Cambridge University Press for further details. For customers in North America, email: subscriptions_newyork@cambridge.org; or phone: (800) 872-7423, option 4. For customers outside of North America, email: journals@cambridge.org; phone: +44 (0)122332-6070; or fax: +44 (0)1223-32-5150.

Postal Information: Periodicals postage rate paid at New York, NY, and at additional mailing offices. POSTMASTER: Send address changes in the USA, Canada, and Mexico to: Slavic Review, Cambridge University Press, Journals Fulfillment Department, One Liberty Plaza, 20th Floor, New York, NY 10006. Send address changes elsewhere to the Slavic Review, Cambridge University Press, Journals Fulfillment Department, UPH, Shaftesbury Road, Cambridge CB2 8BS, England.

Copyright (C) 2017 Slavic Review ISSN 0037-6779 by the Association for Slavic, East European, and Eurasian Studies, Inc. Permission to reprint must generally be obtained from Cambridge University Press. Copying is permitted in accordance with the fair use guidelines of the U.S. Copyright Act of 1976. The association permits the following additional educational uses without permission or payment of fees: academic libraries may place materials from Slavic Review on reserve (in multiple photocopied or electronically retrievable form) for students enrolled in specific courses; teachers may reproduce or have reproduced multiple copies (in photocopied or electronic form) for students in their courses. Those wishing to reproduce material from Slavic Review for any other purpose (general distribution, advertising or promotion, creating new collective works, resale, etc.) must obtain permission from Cambridge University Press. Permissions and reproduction policies, request forms, and contacts are available at: http:// www.cambridge.org/uk/information/rights/permission.htm.

Slavic Review is indexed in ABSEES (American Bibliography of Slavic and East European Studies). Articles appearing in this journal are abstracted or indexed in Historical Abstracts, America: History and Life, ABC Pol Sci: A Bibliography of Contents, Academic Index, Arts and Humanities Citation Index, Linguistic Bibliography, Book Review Index, Historical Abstracts, Humanities Index, MLA, PAIS, RILM, Social Science Index, Social Science Citation Index, Current Contents/Social and Behavioral Sciences, International Bibliography of the Social Sciences, and CrossRef.

The Editorial Office of the Slavic Review is located at the University of Illinois, UrbanaChampaign, and is supported by the College of Liberal Arts and Sciences, the Russian, East European, and Eurasian Center, the Department of Slavic Languages and Literatures, and the Humanities Council.

Articles, books for review, and correspondence concerning editorial matters should be sent to Slavic Review, University of Illinois, 1207 W. Oregon St., Urbana, IL 61801-3716. Telephone: (217) 333-3621; e-mail: slavrev@illinois.edu; website: www.slavicreview.illinois.edu. To advertise in the journal please email USAdSales@cambridge.org or telephone +1(212) 337-5053 in the USA, Canada, or Mexico; email ad_sales@cambridge.org or telephone +44 (1223) 325083 in the rest of the world.

Before submitting manuscripts to Slavic Review, please consult the Information tab on our website for details on criteria, acceptable length, and preparation of the manuscript, available at http://www.slavicreview.illinois.edu/info/manuscripts.html.

Slavic Review does not ordinarily accept unsolicited book reviews. Please consult us if you would like to propose a book for review or a review essay. Slavic Review publishes signed letters to the editor by individuals with educational or research merit. For more detailed policy statements on manuscript submissions, book reviews, and letters to the editor, see our website. 


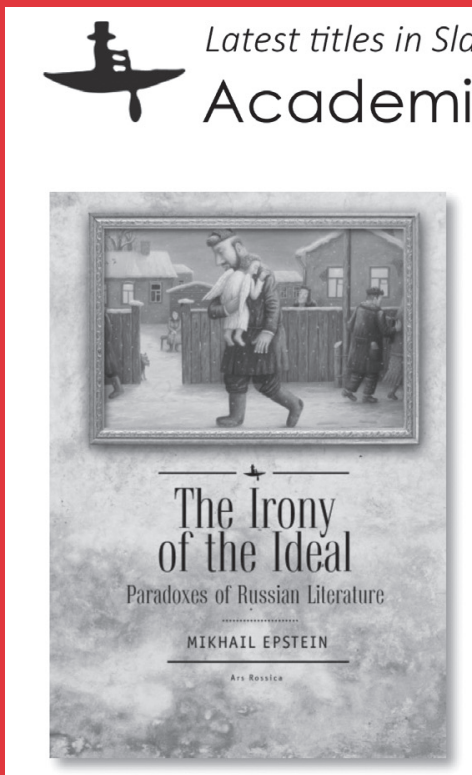

\section{The Irony of the Ideal}

Paradoxes of Russian Literature

MIKHAIL EPSTEIN

Series: Ars Rossica

November 2017 | 9781618116321 | \$119.00 | Cloth

This book explores the major paradoxes of Russian literature as a manifestation of both tragic and ironic contradictions of human nature and national character. Russian literature, from Pushkin and Gogol to Chekhov, Nabokov and to postmodernist writers, is studied as a holistic text that plays on the reversal of such opposites as being and nothingness, reality and simulation, and rationality and absurdity. The glorification of Mother Russia exposes her character as a witch; a little man is transformed into a Christ figure; consistent rationality betrays its inherent madness, and extreme verbosity produces the effect of silence. The greatest Russian writers were masters of spiritual self-denial and artistic self-destruction, which explains many paradoxes and unpredictable twists of Russian history up to our time.

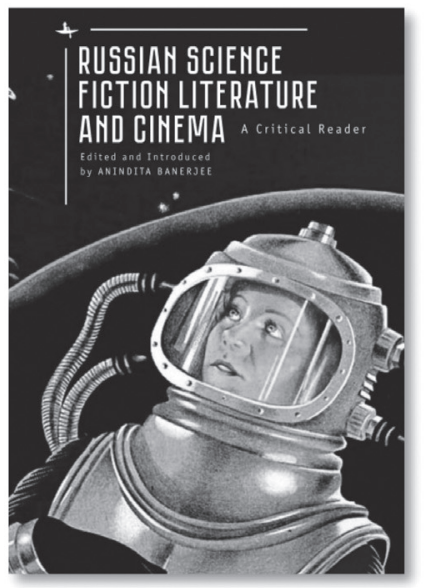

\section{Russian Science Fiction Literature and Cinema}

\section{A Critical Reader}

Edited and introduced by ANINDITA BANERJEE

Series: Cultural Syllabus

February 2018 | 9781618117229 | \$119.00 | Cloth

February 2018 | 9781618117236 | \$49.00 | Paperback

Since the dawn of the Space Age, when the Soviet Union launched the first artificial satellite and sent the first human into the cosmos, science fiction literature and cinema from Russia has fascinated fans, critics, and scholars from around the world. Informed perspectives on the surprisingly long and incredibly rich tradition of Russian science fiction, however, are hard to come by in accessible form. This critical reader aims to provide precisely such a resource for students, scholars, and the merely curious who wish to delve deeper into landmarks of the genre, discover innumerable lesser-known gems in the process, and understand why science fiction came to play such a crucial role in Russian society, politics, technology, and culture for more than a century.

\section{WWW.academicstudiespress.com}

Tel: +1 (617) 782-6290 | press@academicstudiespress.com | 28 Montfern Avenue, Brighton, Massachusetts 02135 